\title{
Assessment of Artificial Recharge Test in Jeftlik - Faria Area, West Bank
}

\author{
Marwan Ghanem ${ }^{1 *}$, Amer Marei ${ }^{2}$, Heinz Hoetzl ${ }^{3}$, Leif Wolf ${ }^{3}$, Wasim Ali ${ }^{3}$, Amjad Assi ${ }^{1}$ \\ ${ }^{1}$ Palestinian Hydrology Group, Ramallah, Palestine \\ ${ }^{2}$ Alquds University, Jerusalem, Plaestine \\ ${ }^{3}$ Karlsruhe University, AGK, Karlsruhe, Germany \\ E-mail: ghanemphg@yahoo.com \\ Received December 31, 2010; revised January 26, 2011; accepted February 27, 2011
}

\begin{abstract}
An artificial recharge test site was selected in the Jeftlik area of the foot prints of the Faria basin, in the Upper Jordan Rift Valley. The artificial pond infiltration type of 26 meters diameter and 2.85 meters depth was used. It is a hyperbolic form of 500 cubic meters volume. The integration parameters of hydrogeological settings, hydrochemical characteristics of allocated water bodies, geophysical investigations and the potentiality of the aquifer system in the area were used for the test area selection. The test site area lies within the shallow Pleistocene aquifer of 30-50 meters saturated thickness. One groundwater well of $19 \mathrm{~m}$ distance and two groundwater wells of $1 \mathrm{~km}$ far distance were used for the system monitoring. The filled water in the test system comes from the wadi water floods brought by $1.5 \mathrm{~km}$ of open canal. The sub-catchment is of $3 \mathrm{~km}^{2}$. The recharge rate within the Pleistocene aquifer was determined. This experiment is tested for the water quality type fillings of the first flushing water floods, the water flood in the middle of the winter season and the pumped water from other wells far away from the experiment.
\end{abstract}

Keywords: Artificial Recharge, Jeftlik Area, Faria Area, Jordan Rift Valley

\section{Introduction}

Water resources in the Jordan Rift valley are scarce in nature. The increasing population growth in the Jordan Rift Valley has put more pressure on the existing limited resources in the region. The steep gradient of the Jordan Valley produces a shadow effect, which reduces the quantity of the rainfall in the Jordan Rift valley [1]. This basin is of great tectonic complexity and the major movement is eastwards with a southerly component near the river Jordan [2]. The aquifer system in the study area includes the sub-aquifers of Quaternary and Neogene formations [3]. This covers the formations of Jenin sub series (Eocene), Beida \& Lisan (Neogene \& Pleistocene) as well as alluvium. The Pleistocene sub-aquifer consists of unconsolidated sand, gravel, cobbles, and boulders of different sizes separated by impermeable layers of saline lacustrine marl deposits [4]. The Eocene deposits are composed of limestone, dolomite, chert, gravel with sand and clay filling the intersect ices and forming alluvial fans. The groundwater occurring in the alluvial fans differs quantitatively and qualitatively according to its loca- tion within the fan. Fresh water occurs around the apex of the fan, whereas saline water occurs at the fringes. Very steep deep faults in the Jordan Rift valley may cause deep circulation of the groundwater bringing it into contact with salty formations which appears as brackish springs near the Jordan River. The study area includes the footprints of the Faria basin in the Jeftlik area (Figure 1). The experiment consists of the construction of the infiltration pond, pumping test of the adjacent wells and hydrochemical characteristics of the adjacent wells. An artificial recharge test site was selected in the Al-Jiftlik area at the edge of the Faria basin in the Upper Jordan Rift Valley. An artificial, cylindrical pond of 26 $\mathrm{m}$ diameter and $2.85 \mathrm{~m}$ depth was used, possessing a volume of $500 \mathrm{~m}^{3}$. It is located within the shallow Pleistocene aquifer of $30-50 \mathrm{~m}$ saturated thickness. The thickness of the undersaturated gravel in the study area is about 20 meters. Three groundwater wells in varying distances $(19-1000 \mathrm{~km})$ were used for the system monitoring. The filling water for the test system originates from the wadi flood waters transported via a $1.5 \mathrm{~km}$ open water canal. 

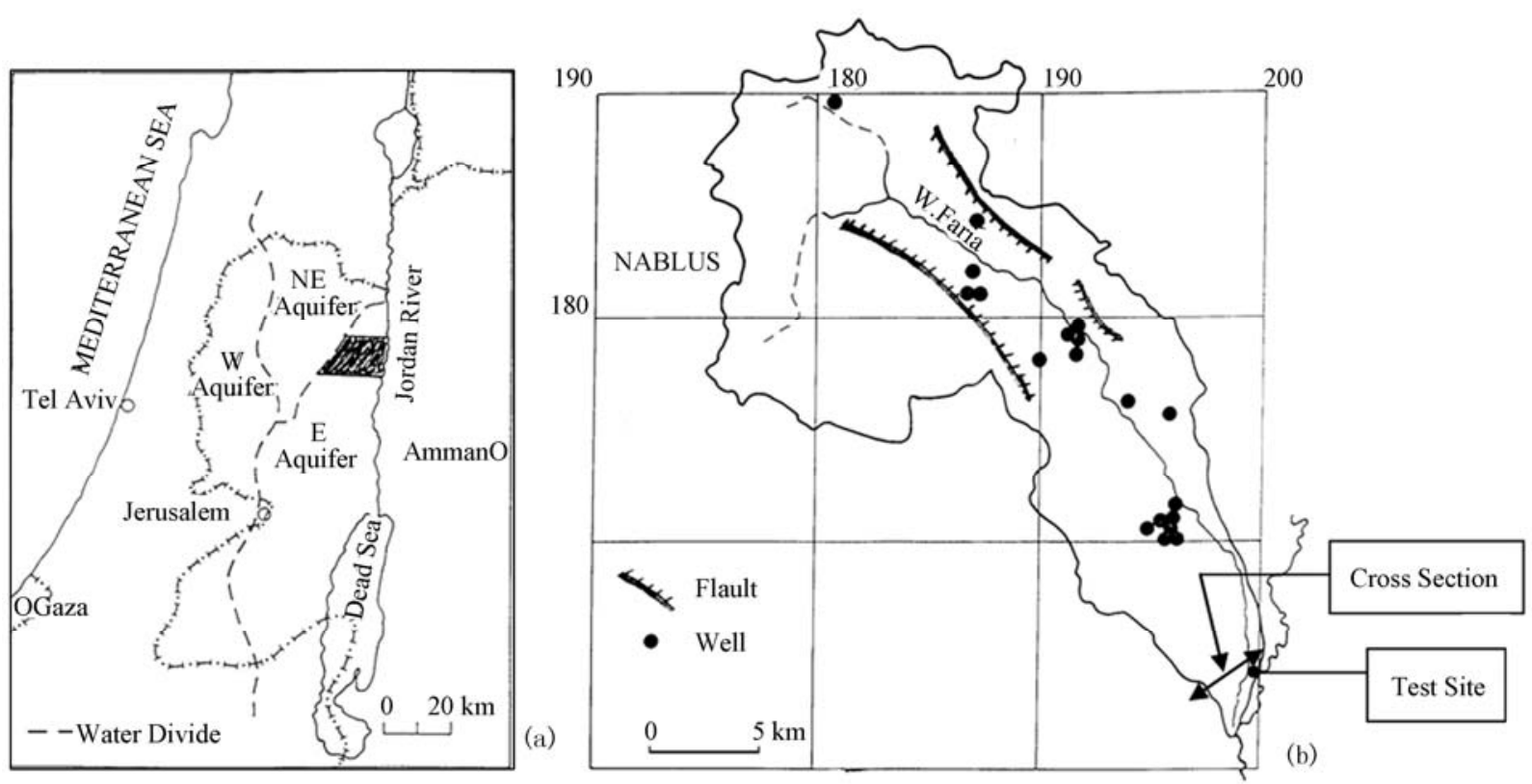

Figure 1. The location map of the artificail recharge infiltration test site in a and the Faria basin in b, where the test site exists.

\section{Methods of the Study}

The major ions $\left(\mathrm{Ca}^{2+}, \mathrm{Mg}^{2+}, \mathrm{Na}^{+}, \mathrm{K}^{+}, \mathrm{Cl}^{-}, \mathrm{SO}_{4}{ }^{2-}, \mathrm{NO}_{3}{ }^{-}\right.$, $\mathrm{HCO}_{3}{ }^{-}$) as well as heavy metals ( $\mathrm{Fe}, \mathrm{Zn}, \mathrm{Li}, \mathrm{Cr}, \mathrm{Co}, \mathrm{Ni}$, $\mathrm{Cu}, \mathrm{Cu}, \mathrm{Mn}, \mathrm{Al}, \mathrm{Cd}, \mathrm{Ba}, \mathrm{Pb}, \mathrm{Bi})$ were analysed. The groundwater samples were collected in one-liter polyethylene bottles and refrigerated in the laboratory at $2^{\circ} \mathrm{C}$. A Sharewood 4010 flame photometer was used to determine calcium, sodium and potassium. A HP 8453 Diode Array Spectrophotometer was used to determine nitrate and sulfate concentrations. A Metrohm 716 titrator used to determine chloride and bicarbonate concentrations. Concentration of trace elements such as iron, copper, zinc, cadmium, lead and arsenic were determined using Graphite furnace Atomic Spectrophotometer. The sampling campaigns was carried out in wet seasons, starting from Nov. - 2008 to January 2009; a total of 19 samples were collected. The Schlumberger method was applied to conduct geoelectrical investigations by using an Earth Resistivity Meter (ERM) in order to draw geophysical profiles of the Al-Jiftlik area. Using AquiChem softwarePhysical and chemical properties of the aquifer were determined from eight target wells existing in the study area.

\section{Results and Discussions}

\subsection{Construction of the Infiltration Pond}

The first phase of the experiment was carried out in the pilot area in construction of the infiltration pond. Table 1 illustrates the coordinates as well as the volume needed measurements of the infiltration pond. The volume of the pond is calculated according to the hyperbolic formulas according to the equation derived from Figure 2.

$V=(1 / 3) \pi h\left(r_{12}+r_{1} r_{2}+r_{22}\right)$; where

$V \quad$ volume of the pond

$h$ dynamic elevation of the water in the pond

$r_{1}, r_{2} \quad$ lower and the upper radius of the pond

The infiltration rate is found to be $6 \mathrm{~cm}$ after seven days of the experiment. Three centimetres in the third day of the experiment, $2 \mathrm{~cm}$ in the fifth day and one $\mathrm{cm}$ in the sixth day were recorded. The water in the pond is infiltrated in the Alluvium aquifer of the adjacent well. The travel time is found to be three days for the 19 meters distance.

\subsection{Groundwater Hydrochemistry}

Nineteen groundwater wells were investigated hydro-

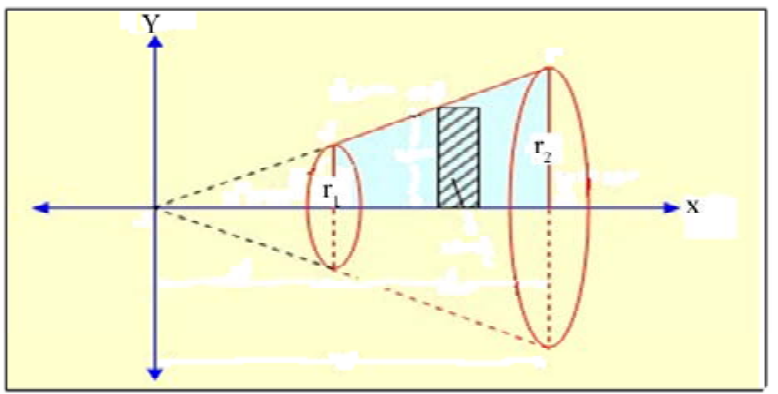

Figure 2. The schematic shape of the artificial recharge pond and its equation. 
Table 1. Coordinates and measurements of the Artificial recharge pond (in meters).

\begin{tabular}{ccccccccccc}
\hline Day & Date & Time & H (in pond) & D (in pond) & H (in well) & r1 & r2 & Vw & $\Delta \mathbf{V}$ & $\Delta \mathbf{h}$ \\
\hline Monday & $29 / 12 / 2008$ & $9: 00$ & 102 & 13.9 & 27.96 & 3.65 & 6.95 & 92.8732 & & \\
Thursday & $1 / 1 / 2009$ & $13: 40$ & 75 & 11.9 & 27.96 & 3.65 & 5.95 & 55.2974 & 37.5758 & 0 \\
Thursday & $1 / 1 / 2009$ & $18: 00$ & 72 & 11.87 & 27.96 & 3.65 & 5.935 & 52.9099 & 2.3875 & 0 \\
Friday & $2 / 1 / 2009$ & $8: 00$ & 69 & 11.8 & 27.93 & 3.65 & 5.9 & 50.3139 & 2.59599 & 0.03 \\
Friday & $2 / 1 / 2009$ & $12: 00$ & 67 & 11.78 & 27.93 & 3.65 & 5.89 & 48.7472 & 1.56665 & 0 \\
Friday & $2 / 1 / 2009$ & $18: 00$ & 62 & 11.6 & 27.91 & 3.65 & 5.8 & 44.2135 & 4.53377 & 0.02 \\
Saturday & $3 / 1 / 2009$ & $7: 00$ & 57 & 11.5 & 27.9 & 3.65 & 5.75 & 40.1944 & 4.01902 & 0.01 \\
\hline
\end{tabular}

$\mathrm{H}$ (in pond): Elevation of the pond, D (in pond): Diameter of the pond, $\mathrm{H}$ (in well): Elevation of water in the well, ri and r2: lower and upper radius of the pond, respectively, $\mathrm{Vw}$ : Volume of water in the pond, $\Delta \mathrm{V}$ : change of water in the pond, $\Delta \mathrm{h}$ : change of water elevation in the well.

chemically in the well field of the artificial recharge test in Jeftlik - Faria area (Figure 3). The major ions of $\mathrm{Ca}^{2+}$, $\mathrm{Mg}^{2+}, \mathrm{Na}^{+}, \mathrm{K}^{+}, \mathrm{Cl}^{-}, \mathrm{NO}_{3}^{-}, \mathrm{SO}_{4}{ }^{2-}$ as well as the trace elements of $\mathrm{Fe}, \mathrm{Zn}, \mathrm{Li}, \mathrm{Cr}, \mathrm{Co}, \mathrm{Ni}, \mathrm{Mn}, \mathrm{Al}, \mathrm{Cd}, \mathrm{Ba}, \mathrm{Pb}, \mathrm{Bi}$ were analysed.

Graphical and statistical methodologies were used to classify the water samples according to their main constituents. Water types of these wells are in the field of $\mathrm{Na}$ $-\mathrm{Cl}$ type. Piper diagrams were plotted for all the water samples analyzed in terms of major ions using AquaChem 5.1 software. The samples collected from the wells show that the majority falls into the earth alkaline water with increased portions of alkalis (prevailing sulfate and chloride) with the exception of one well (19-17/008) which is classified as alkaline water with sulfate-chloride characterized by its high TDS and originates by leaching salt bearing rocks (Figure 4 and Figure 5). EC-values

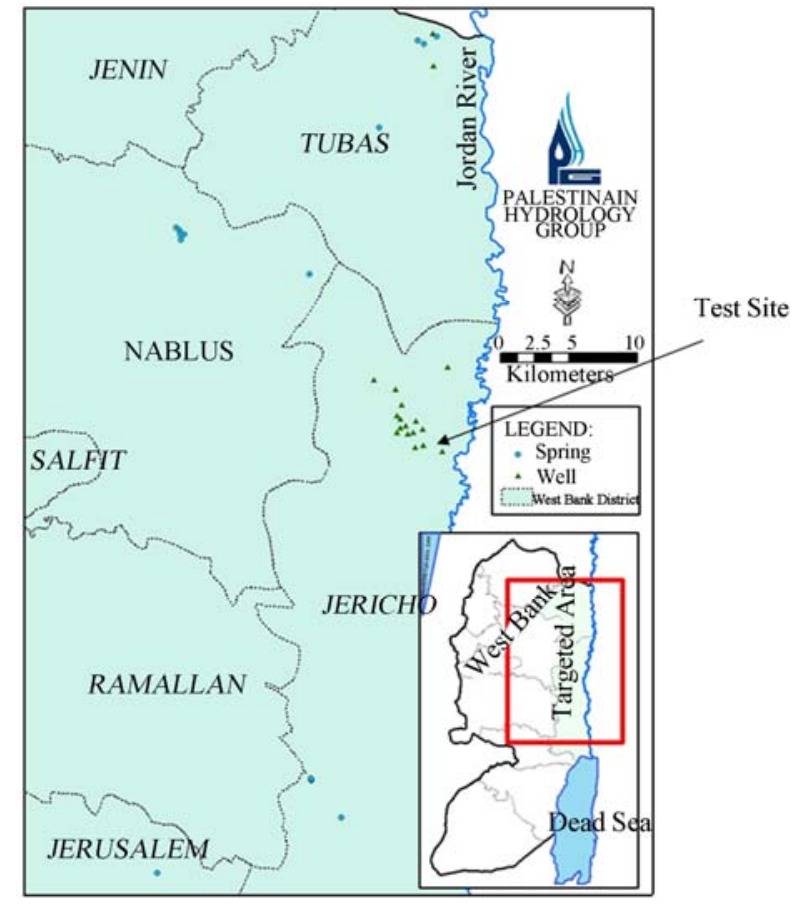

Figure 3. Sampled sites of the groundwater wells. are ranging between 2,100 and 4,700 $\mu \mathrm{S} / \mathrm{cm}$ (Figure 6).

The well samples have the following ionic strength for the major ions: $\mathrm{Na}^{+}>\mathrm{Ca}^{2+}>\mathrm{Mg}^{2+}>\mathrm{K}^{+}$and $\mathrm{Cl}^{-}>$ $\mathrm{HCO}_{3}^{-}>\mathrm{SO}_{4}^{2-}>\mathrm{NO}_{3}^{-}$. The analyzed parameters were also subjected to produce linear correlation analysis. A correlation matrix is a symmetric square matrix whose entries are called correlation coefficients and main diagonal is all one unit.

Correlation coefficients were calculated for all possible pairs of variables. The results of the saturation index showed that all the groundwater samples were found to be undersaturated with respect to calcite, aragonite and dolomite minerals. On the other hand, the situation may be rendered complex by influences such as mixing of unlike water, interconnected aquifers of different composition, chemical reactions such as cation exchange and adsorption of dissolved ions and biological influences.

\subsection{Pumping Test Analyses}

Pumping test were implemented for 9 groundwater wells in Al Fara'- Jeftlik area, in order to identify the characteristics of the aquifer; such as Transmissivity (T) and Storativity (S), to check the ability of water to be transmitted (Table 2). Pumping test was implemented with a test duration of each test was less than one day.

The calculated transmissivity $(\mathrm{T})$ of these wells are ranging between $86-4763 \mathrm{~m}^{2} /$ day. This variability of T in the area is due to the existing of faults in the area, during the formation of the Jordan Rift Valley. The nearest groundwater well named 19-17/28 has a static head equal to $26.23 \mathrm{~m}$ and dynamic head $26.5 \mathrm{~m}$. The pumping rate is ranging between $80-100 \mathrm{~m}^{3} / \mathrm{hr}$. It's transmissivity is calculated to be $86 \mathrm{~m}^{2}$ per day.

\subsection{Geophysical Investigations}

Vertical electric sounding (VES) profiles during the artificial recharge test site were selected in the Al-Jiftlik area at the edge of the Faria basin in the Upper Jordan Rift Valley (Figure 1). The results of VES profiles show that 


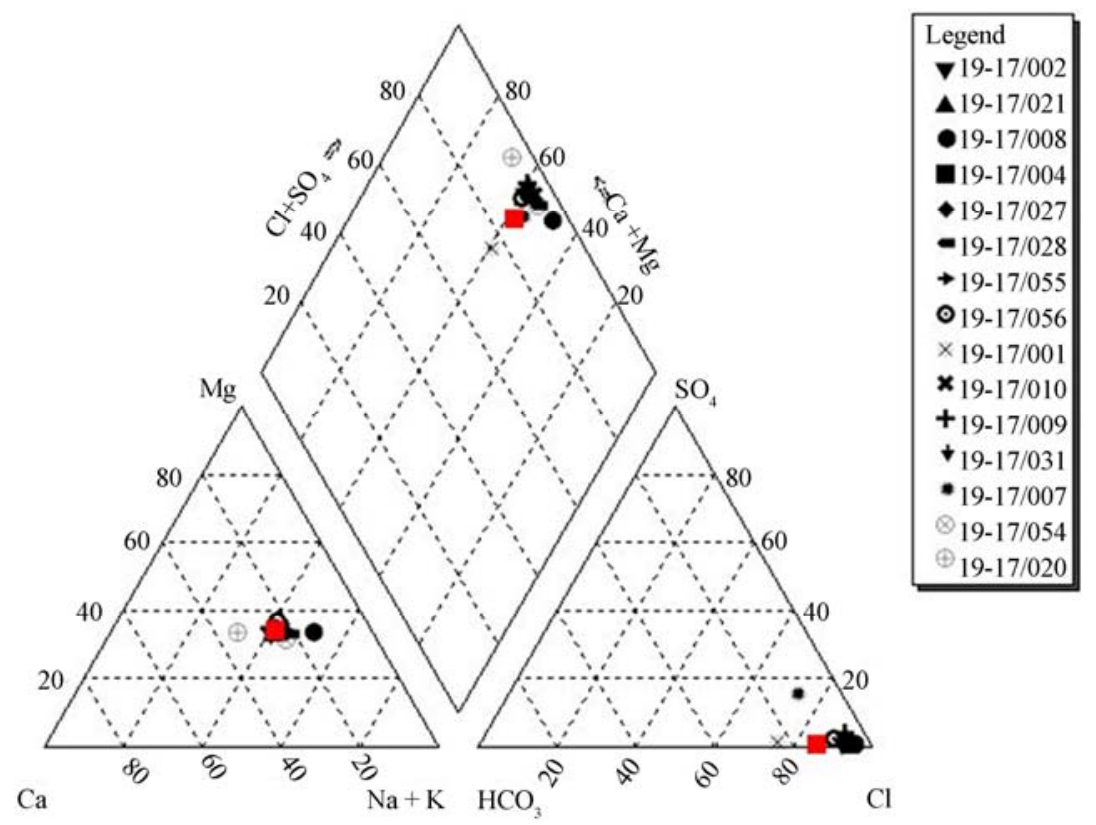

Figure 4. General Piper Diagram for the wells.

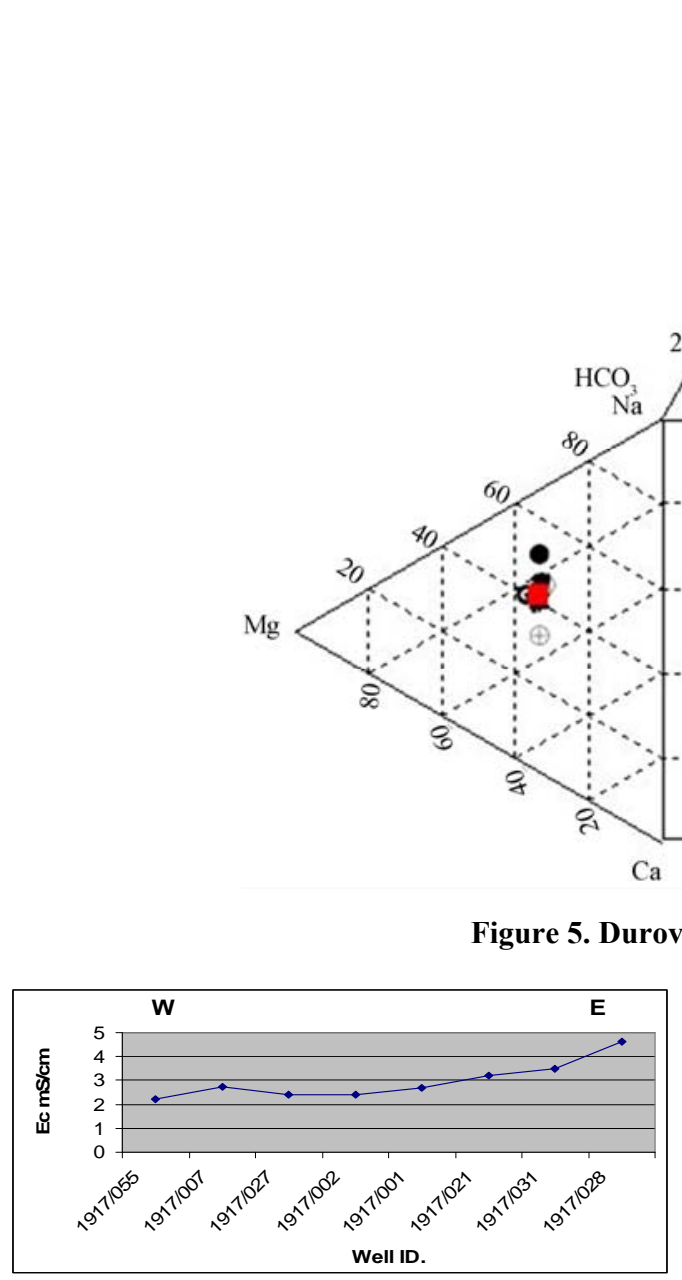

Figure 6. EC of the wells in the studied area.

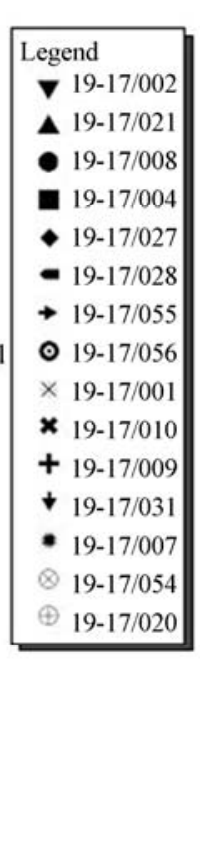

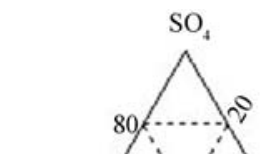
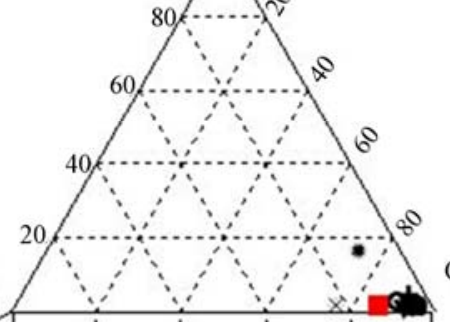

ov diagram for the well samples. 
Table 2. The coordinates of the Pumping groundwater wells.

\begin{tabular}{cccccc}
\hline No & Well Name & Well Id. & X & Y & Z in meters \\
\hline 1 & Waheed Al Masri & $19-17 / 002$ & 196520 & 171240 & -253 \\
2 & 'Allan Al Damen \& Partners & $19-17 / 008$ & 196250 & 170250 & -251 \\
3 & Burhan Al Damen & $19-16 / 008$ & 196780 & 169670 & -260 \\
4 & Fareed Abu Shamat & $19-17 / 028$ & 198150 & 170500 & -268 \\
5 & 'Inad Al Masri & $19-17 / 001$ & 196900 & 170740 & -255 \\
6 & Husain Drai'i & $19-17 / 010$ & 197060 & 170150 & -262 \\
7 & Rafeeq Qamhawi & $19-17 / 009$ & 197470 & 170230 & -264 \\
7 & 'Abed Al Lateef Haydar & $19-17 / 031$ & 197680 & 171060 & -265 \\
9 & Fathalla Al Masri & $19-17 / 007$ & 196640 & 172290 & -244 \\
\hline
\end{tabular}

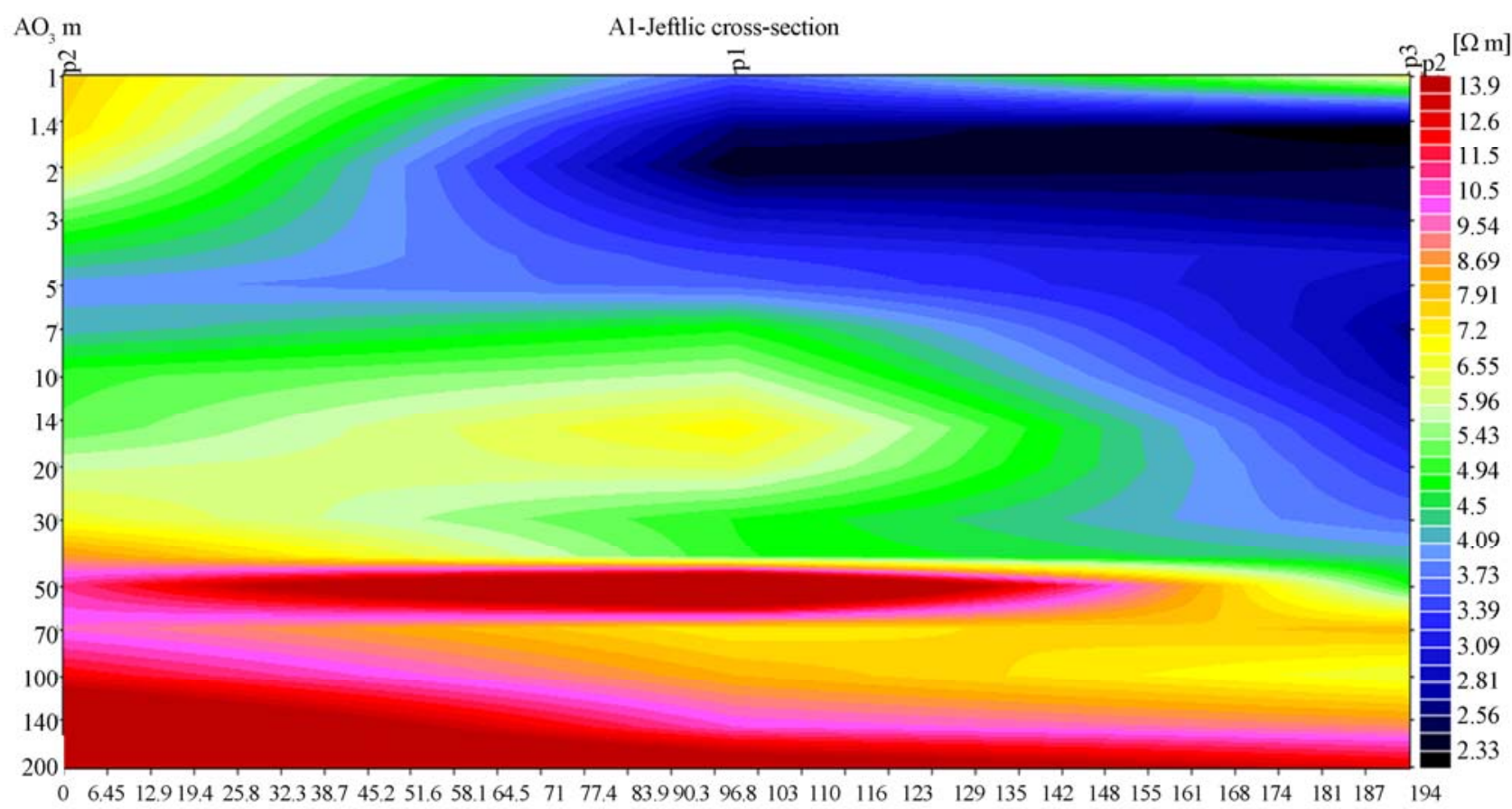

Figure 7. VES east profiles in the Al-Jiftlik area (x axis: distance, $Y$ (left): earth depth, $Y$ (right): resistivity).

be used to store flood water. The geophysical investigation methods concluded to the five sub-layers that are located within the unconfined aquifer systems. These sub -layers are related to the Pleistocene-Neogene age and the Cenomanian age.

\subsection{Soil Texture}

The soil texture is dominated by clay to clayey loam (Figure 8). It has a low infiltration potential and a high runoff potential. The hydraulic conductivity has an average of $2 \times 10^{-5}-9 \times 10^{-5} \mathrm{~m} / \mathrm{s}$.

\section{Conclusions}

An artificial recharge test site was selected in the Jeftlik area of the foot prints of the Faria basin, in the Upper
Jordan Rift Valley. The artificial pond infiltration type of 26 meters diameter and 2.85 meters depth was used it is a hyperbolic form of 500 cubic meters volume. The integration parameters of hydrogeological settings, hydrochemical characteristics of allocated water bodies, geophysical investigations and the potentiality of the aquifer system in the area were used for the understanding of the physical processes of the experiment. The test site area lies within the shallow Pleistocene aquifer of $30-50$ meters saturated thickness. One groundwater well of 19 $\mathrm{m}$ distance and two groundwater wells of $1 \mathrm{~km}$ far distance were used for the system monitoring. The filled water in the test system comes from the wadi water floods brought by $1.5 \mathrm{~km}$ water open canal. The recharge rate within the Pleistocene aquifer was determined. This experiment is tested for the water quality type fillings of the first flushing water floods. The thickness of the un- 


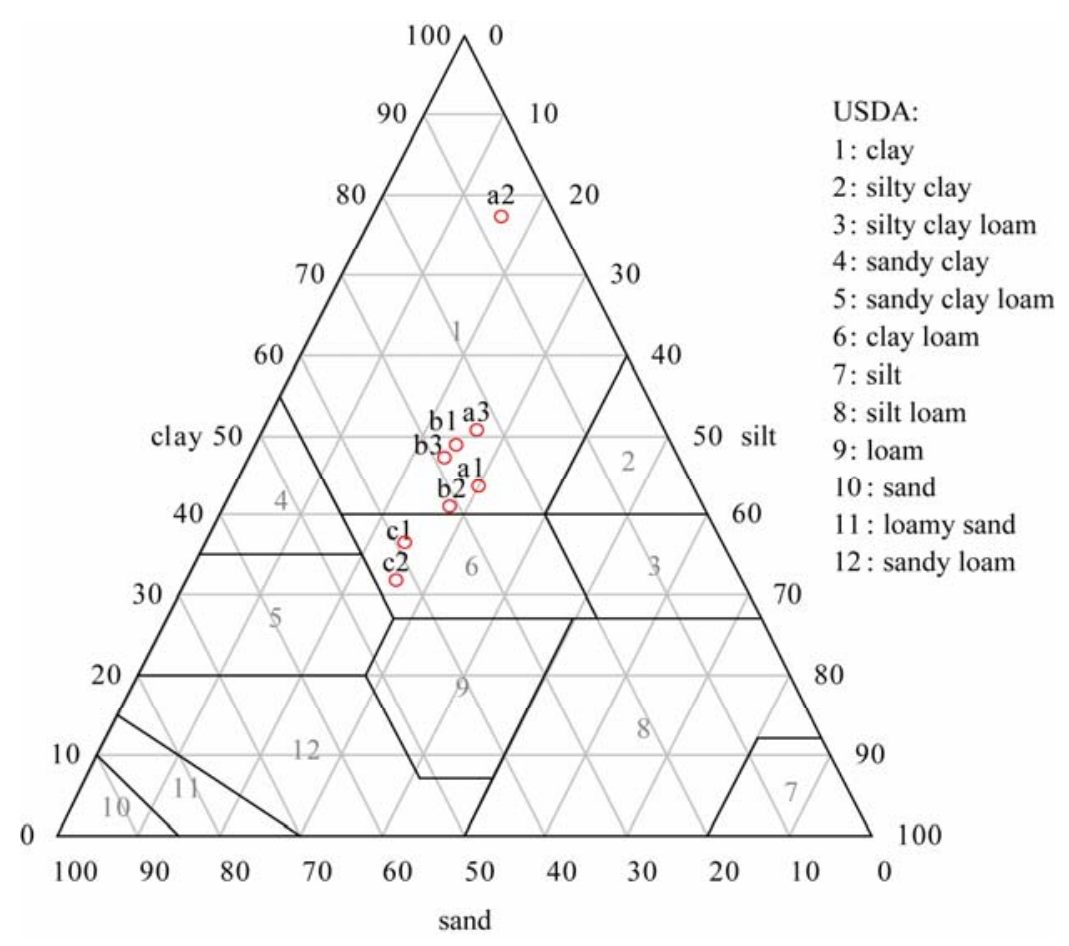

Figure 8. Texture triangle for Al-Jiftlik soil samples.

saturated gravel aquifer in the lower part of Al-Jiftlik is about $20 \mathrm{~m}$. This layer could be used to store flood water. The geophysical investigation methods concluded to the five sub-layers that are located within the unconfined aquifer systems. These sub-layers are related to the Pleistocene-Neogene age and the Cenomanian age. The lower eastern zone of the study area is facing a huge salinization problem of aquifer water, while the nitrate pollution is less notable there. Groundwater salinity increases towards the east where the Lisan Formation is dominant, and it emerges through a long duration time and caused by the reactions between fresh water, marl, clay and minerals of the Lisan Formation, especially in the lower part of the study area, and the over pumping of the groundwater wells. Furthermore, the artificial recharge experiment in the Faria catchment is necessary in order to get an actual idea about the groundwater potentiality. Within the scope of further investigations, the recharge rate of the Pleistocene aquifer should be determined and compared to the calculated transmissivity value that was extracted from the conducted pumping test campaign of pre-test investigations.

\section{Acknowledgements}

The authors express their thanks to the BMBF in Germany for their financial support of the experiment.

\section{References}

[1] A. Arad and A. Michaeli, "Hydrogeological Investigation in the Western Catchment of the Dead Sea," Israeli Journal of Earth Sciences, Vol. 16, No. 4, 1967, pp. 181-196.

[2] Y. Guttman, "The Hydrology of the Eastern Basin and Possibilities for the Development of Water Resources from the Pharaoh Stream to the Judean Desert," Tahal, Tel Aviv, 1995.

[3] M. Ghanem, "Hydrogeology and Hydrochemistry of Faria Drainge Basin," Freiberger Heft, 1999.

[4] Rofe and Raffetey Consulting Engineering, "West Bank Hydrology: Nablus District Water Resources Survey," Geological and Hydrological Report, 1965. 